\title{
Rancang Bangun Sistem Informasi Manajemen Surat Tugas Berbasis Web Menggunakan Waterfall Model
}

\author{
Agus Cahyo Nugroho \\ Jurusan Sistem Informasi, Fakultas Ilmu Komputer, Unika Soegijapranata, Semarang \\ J1. Pawiyatan Luhur IV/1 Bendan Dhuwur, Semarang, Jawa Tengah, Indonesia \\ email: agus.nugroho@unika.ac.id
}

Copyright $@ 2019$, Politeknik Harapan Bersama, Tegal

\begin{abstract}
Letter of Assignment is something that can't be separated in the management of University. A lecturer works on a specific task based on the assignment letter he receives from either the Department Leader or the University Leader. In the Department this matter is handled by the Department Administrator who handles the operations of the Department daily. If this is still handled manually, of course it will bother the Department Administrator. Especially when Department Administrator workload is high causing human error to occur. Web-based Letter of Assignment Information System is the solution to this problem. This system is developed to facilitate the operation of the Department. Besides documents that are already in digital form make it easy in terms of storage and distribution. So that both the Department Administrator and the Lecturer can access the assignment letter from wherever he is as long as there is still an internet connection. This system was developed using the Waterfall Model method which is one of the classic and most popular methods in software development. Research conducted based on qulitative analysis of primary and secondary data sources with methods of collecting data through observation, interviews and documentation. The implementation of this system is succeeded to facilitate operations in the Department so that the Department Administrator can work more effectively and efficiently.
\end{abstract}

Abstrak - Surat tugas merupakan sesuatu yang tidak bisa dipisahkan dalam manajemen Perguruan Tinggi. Seorang dosen mengerjakan tugas tertentu berdasarkan surat tugas yang diterimanya baik dari Pimpinan Program Studi maupun Pimpinan Perguruan Tinggi. Pada Program Studi hal ini ditangani oleh Admin Prodi yang sehari-hari menangani operasional Program Studi. Jika hal ini masih ditangani secara manual tentunya merepotkan Admin Prodi. Terutama saat beban kerja Admin Prodi sedang tinggi menyebabkan kemungkinan human error terjadi. Sistem Informasi Surat Tugas Berbasis Web merupakan solusi dari permasalahan ini. Sistem ini dikembangkan untuk memperlancar operasional Program Studi. Selain itu dokumen yang sudah dalam bentuk digital memudahkan dalam hal penyimpanan dan distribusi. Sehingga baik Admin Prodi maupun Dosen dapat mengakses surat tugas dari mana pun dia berada selama masih ada koneksi internet. Sistem ini dikembangkan menggunakan metode Waterfall Model yang merupakan salah satu metode klasik dan paling populer dalam pengembangan perangkat lunak. Penelitian yang dilakukan berdasarkan analisis kualitatif terhadap sumber data primer maupun sekunder dengan metode pengumpulan data melalui observasi, interview dan dokumentasi. Implementasi dari sistem ini telah berhasil

*) penulis korespondensi: Agus Cahyo Nugroho

Email: agus.nugroho@unika.ac.id memperlancar operasional di dalam Program Studi sehingga Admin Prodi dapat bekerja secara lebih efektif dan efisien.

Kata Kunci - surat tugas, waterfall model, sistem informasi, sdlc, universitas.

\section{PENDAHULUAN}

Sistem administrasi manajemen surat tugas yang digunakan oleh sebuah PTS di Surabaya sekarang ini masih manual. Sistem administrasi manajemen surat tugas yang manual ini sangat bergantung kepada kemampuan Admin Program Studi. Apabila pekerjaan Admin Program Studi sedang tidak banyak maka proses pembuatan surat tugas ini dapat berlangsung dengan cepat. Demikian untuk sebaliknya. Meskipun sudah ada template dari surat tugas tersebut dalam file Microsoft Word. Sehingga Admin Program Studi tinggal mengedit file tersebut. Selain itu kendala lain adalah dokumentasi dari surat tugas tersebut dalam bentuk file Microsoft Word ada kemungkinan tertumpuk dengan file surat tugas milik orang lain apabila Admin Program Studi kurang teliti saat merename nama file template.

Oleh karena itu pembuatan sistem informasi surat tugas ini sangat diperlukan untuk mengatasi permasalahan di atas. Sistem informasi surat tugas ini dikembangkan dengan tujuan untuk dapat membantu proses pembuatan surat tugas menjadi lebih cepat, mudah dan terdokumentasi dengan baik. Selain itu dengan sistem informasi surat tugas ini dosen juga bisa langsung mengakses surat tugasnya masing-masing untuk dapat mencetak dalam bentuk pdf maupun mencetak dalam bentuk berkas. Hal ini tentunya memudahkan dosen terlebih saat tugas di luar kantor namun membutuhkan surat tugas tersebut. Ditambah lagi hal ini tentunya meringankan tugas Admin Program Studi karena dosen dapat secara mandiri mengerjakan administrasi yang terkait surat tugasnya masingmasing. Admin Program Studi juga dapat melacak surat tugas yang sudah dikeluarkan untuk masing-masing dosen di Program Studi tersebut.

\section{PENELITIAN YANG TERKAIT}

Penelitian terdahulu dilakukan oleh Jati Sasongko dan Dwi Agus Diartono dengan judul Rancang Bangun Sistem Informasi Manajemen Surat [1] dan Muhammad Luqman dengan judul Pembangunan Sistem Informasi Manajemen Surat Masuk dan Surat Keluar pada Bagian Umum Sekertariat Daerah Kabupaten Pacitan [2]. Kedua penelitian tersebut berhasil membuat Sistem Informasi Manajemen Surat untuk 
mengatasi permasalahan yang ada. Penelitian berikutnya oleh Nanda Lutfian Gunawan berjudul Rancang Bangun Aplikasi Manajemen Surat Berbasis Web pada Dinas Perhubungan Kota Surabaya [3] dengan kesimpulan berdasarkan hasil pengujian dan evaluasi, diketahui bahwa surat aplikasi manajemen berbasis web mampu memberikan kemudahan penerimaan surat masuk dari internal dan eksternal, untuk mencatat, mengarsipkan dan mendistribusikan hingga mengirim surat keluar. Penelitian lain oleh Rifeldo Praguna berjudul Sistem Informasi Manajemen Kearsipan di SMK Negeri 5 Padang Provinsi Sumatra Barat [4] dengan kesimpulan hasil yang didapat dari implementasi sistem informasi manajemen arsip di SMK 5 Negeri Padang adalah pengarsipan surat yang dulunya manual sekarang digital memudahkan dalam hal pengelolaan. Joko Agus Prawono juga sudah melakukan penelitian berjudul Sistem Informasi Pengelolaan Surat Masuk dan Keluar di STMIK AUB Surakarta [5] dengan kesimpulan sistem yang paling praktis dan efisien dalam menangani surat masuk dan keluar adalah menggunakan sistem nomor pengagendaan, sehingga setiap surat masuk dan keluar baik secara internal maupun secara eksternal dapat direkam dalam agenda. Terakhir Sharipuddin juga sudah melakukan penelitian berjudul Analisis dan Perancangan Sistem Informasi Pengelolaan Surat pada STIKOM Dinamika Bangsa Jambi [6] dengan hasil akhir implementasi sistem informasi manajemen surat di Sekolah Tinggi Ilmu Komputer Dinamika Bangsa Jambi.

Penulis mencoba melakukan sebuah penelitian dengan menggunakan metode Waterfall Model untuk menyelesaikan permasalahan administrasi manajemen surat tugas di sebuah PTS di Surabaya yang masih dilakukan secara manual. Metode Waterfall Model merupakan suatu metode pengembangan perangkat lunak secara klasik yang hingga saat ini masih banyak digunakan.

\section{METODE PENELITIAN}

Sistem Informasi adalah kombinasi dari user, perangkat keras (hardware) dan perangkat lunak (software) yang saling bekerja sama dalam mengolah data untuk menghasilkan informasi yang berguna bagi perusahaan [7].

Sistem Informasi juga mempunyai pengertian sebuah sistem yang dikembangkan oleh manusia dimana mengadopsi komponen organisasi yang kemudian digunakan untuk menyajikan informasi. Sistem Informasi mempunyai tujuan menyajikan informasi yang berkualitas, tepat, cepat dan akurat sehingga dapat memperlancar proses di dalam organisasi selain itu membantu manajemen perusahaan di dalam proses pengambilan keputusan.

Waterfall model adalah salah satu model pengembangan perangkat lunak yang paling lama dan paling terkenal. Model ini awalnya digunakan oleh perusahaan yang mengembangkan perangkat lunak pada skala besar untuk Departemen Pertahanan dan Luar Angkasa Amerika Serikat sekitar tahun 1960 [8]. Perusahaan ini bekerja dalam beberapa proyek jangka panjang antara lain mendesain perangkat lunak untuk komputer mainframe yang perkembangannya relatif lambat.

Perusahaan tersebut memodelkan proses dalam bentuk waterfall setelah tahap desain hardware hal ini dilakukan supaya insinyur dapat memprediksi bagaimana bagian-bagian kecil dari sistem saling berinteraksi. Cara kerja metode ini adalah menyelesaikan sebuah tahap sebelum berlanjut ke tahap berikutnya seperti pada Gambar 1 [9]. Secara umum metode ini tidak kembali ke tahap sebelumnya setelah berlanjut ke tahap berikutnya. Tahap dalam metode waterfall ini terus bergerak maju. Setiap tahap bergantung dari informasi dari tahap sebelumnya. Model ini memberikan kesempatan untuk kembali ke tahap sebelumnya tetapi hal ini menyebabkan biaya tambahan dalam hal penulisan ulang dokumentasi maupun pengembangan aplikasi. Jika penundaan terjadi, maka keseluruhan proyek dan timeline akan berubah. Model waterfall mudah dipahami dan dikelola di seluruh siklus pengembangan sistem.

Beberapa keunggulan waterfall model antara lain sederhana, mudah dipahami dan diimplementasikan. Waterfall model bekerja dengan baik dan memberikan hasil yang benar. Model ini banyak digunakan dan diakui dalam industri pengembangan perangkat lunak. Tahap yang digunakan ketat dan tepat, setiap tahap di eksekusi satu per satu, sehingga mudah untuk dikelola. Kriteria awal dan akhir di definisikan dengan baik sehinga mudah untuk di kelola. Hal ini menjamin kualitas dan tercapainya tujuan. Fokus dari model ini adalah dokumentasi yang baik. Keuntungan terbesar dari waterfall model dalam siklus pengembangan perangkat lunak adalah menyediakan struktur untuk mengatur dan mengendalikan proyek pengembangan perangkat lunak. Hal terpenting dalam pendekatan siklus pengembangan perangkat lunak waterfall model ini adalah mengidentifikasi kebutuhan pengguna secara akurat.

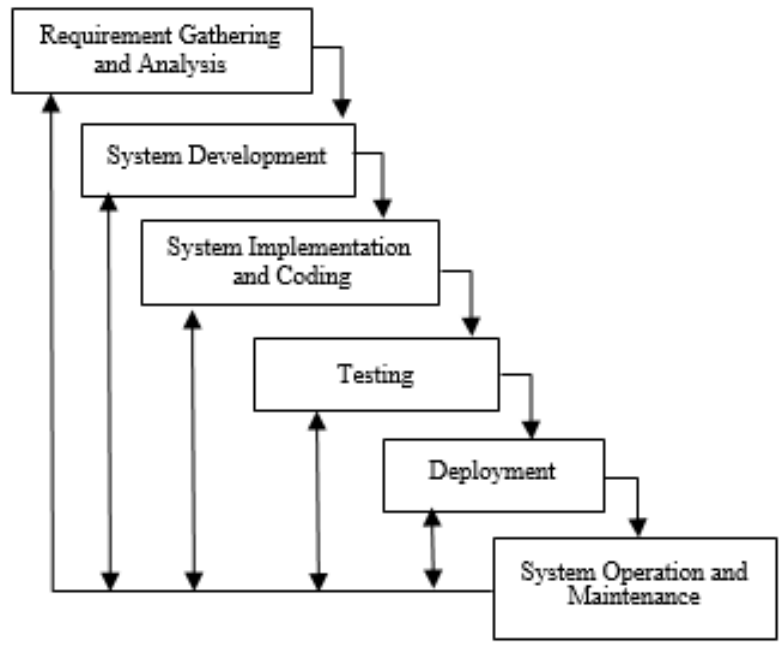

Gbr. 1 Diagram waterfall model

Kelemahan dari waterfall model adalah tidak dapat mengakomodasi perubahan besar dalam hal kebutuhan di tengah proyek. Jika aplikasi sudah sampai ke tahap pengujian dan terjadi perubahan kebutuhan atas dasar permintaan sponsor proyek maka menyulitkan kita untuk kembali dan mengubahnya. Hal lain adalah terkait proses pengiriman produk akhir yang lama. Salah satu penyebabnya adalah tidak ada prototipe yang tersedia sebelumnya untuk dibandingkan dengan aplikasi yang sedang dikembangkan. Tidak adanya prototipe ini juga secara tidak langsung meningkatkan resiko kesalahan. Karena pengujian dilakukan pada tahap selanjutnya maka tidak dimungkinkan untuk mengidentifikasi tantangan dan resiko pada tahap sebelumnya. Hal ini mempersulit strategi untuk mengurangi resiko kesalahan yang mungkin terjadi. Membuat perubahan pada dokumen juga 
membutuhkan biaya yang mahal karena dilakukan di tiap tahap baik itu untuk masalah kecil maupun besar.

Proses desain dalam penelitian ini menggunakan Unified Modeling Language (UML). UML adalah bahasa grafis untuk menampilkan visualisasi, spesifikasi, konstruksi dan dokumentasi setiap artifak dari perangkat lunak [unsrat]. Diagram $U M L$ yang digunakan dalam penelitian ini adalah Use Case Diagram.

Menurut Alistair Cockburn [7], Use Case Diagram menggambarkan kontrak untuk perilaku. Kontrak adalah bagaimana cara aktor menggunakan sistem tersebut untuk menyelesaikan permasalahan yang di hadapi. Sedangkan bahasa pemrograman yang digunakan dalam penelitian ini adalah Hypertext Preprocessor (PHP). PHP menurut Sharive [10] adalah bahasa pemrograman server-side dalam pengembangan web yang bisa disisipkan dalam dokumen Hyper Text Markup Language (HTML). PHP memungkinkan web menjadi dinamis sehingga pemeliharaan web dapat menjadi lebih efektif dan efisien [11]. Database dalam penelitian ini menggunakan MySQL. MySQL merupakan salah satu aplikasi open source yang termasuk dalam Database Management System (DBMS). DBMS adalah sistem yang dikembangkan dengan tujuan memudahkan dalam mengelola database.

Pendekatan penelitian yang digunakan adalah penelitian kualitatif. Pendekatan ini dipilih karena dapat mendeskripsikan analisis kondisi dan prosedur yang berjalan selama ini di sebuah PTS di Surabaya dan untuk merancang Sistem Informasi Manajemen Surat Tugas [12]. Terdapat 2 jenis data di dalam penelitian yaitu :

- Data Primer, adalah sumber data yang langsung memberikan data kepada pengumpul data.

- Data Sekunder, adalah sumber data yang didapat dengan cara membaca, mempelajari dan memahami melalui berbagai media bersumber dari literatur, buku-buku dan arsip/dokumen perusahaan.

Penelitian ini menggunakan jenis data primer yang berupa data wawancara kepada Admin Prodi dan Kaprodi di sebuah PTS di Surabaya sedangkan data sekunder yang berupa data institusi yaitu arsip/dokumen surat tugas, daftar dosen dan lain-lain. Teknik pengumpulan data yang dilakukan menggunakan metode wawancara dan observasi, penulis melakukan wawancara terhadap beberapa informan antara lain Admin Prodi yang terbiasa dalam mengerjakan surat tugas dan Kaprodi. Sedangkan observasi dilakukan dengan cara membaca dan memahami Standard Operating Procedure (SOP) yang selama ini telah berjalan. Berdasarkan wawancara yang telah dilakukan ditemukan beberapa kelemahan dan solusi yang diinginkan perusahaan untuk mengatasi beberapa permasalahan yang muncul. Selain itu juga dilakukan analisis terhadap dokumen yang ada di dalam perusahaan. Berikut teknik pengumpulan data yang digunakan :

1) Metode Observasi, dilaksanakan dengan mengadakan kunjungan langsung ke sebuah PTS di Surabaya dengan tujuan untuk mengetahui bagaimana seluruh kegiatan manajemen surat tugas yang selama ini dilakukan serta melihat format surat tugas yang ada.

2) Metode Interview, dilaksanakan dengan menggali data perusahaan baik dari sejarah, profil perusahaan, visi misi perusahaan sampai informasi bagaimana proses dan alur pembuatan surat tugas yang selama ini dikerjakan.
3) Metode Dokumentasi, dilaksanakan dengan melihat data-data tertulis yaitu berupa dokumen-dokumen perusahaan seperti pencatatan surat tugas yang keluar maupun masuk.

Penelitian ini menggunakan teknik analisis data kualitatif dengan merancang Sistem Informasi Manajemen Surat Tugas pada sebuah PTS di Surabaya. Dari permasalahan yang muncul yaitu tentang manajemen surat tugas yang masih manual maka diambil sejumlah data yang kemudian di analisis sesuai kebutuhan dari Sistem Informasi Manajemen Surat Tugas yaitu data jabatan, data petugas, data prodi, data transaksi dan data unit. Hasil analisis akan dirancang dengan menggunakan flowchart dan implementasi program. User Interface Sistem Informasi Manajemen Surat Tugas ini menggunakan warna dasar putih dengan kombinasi warna lain yang sesuai. Selain itu akan digunakan CSS Template yang sederhana sehingga diharapkan memudahkan admin prodi maupun dosen yang akan menggunakan aplikasi ini.

Admin prodi maupun dosen dapat login ke dalam aplikasi ini menggunakan username dan password masing-masing dengan hak akses yang berbeda. Setelah berhasil login ke dalam sistem admin prodi dapat menginput surat tugas baru, mengedit surat tugas yang pernah dibuat, menghapus surat tugas dari daftar surat maupun mendownload atau mencetak surat tugas. Sedangkan untuk dosen setelah berhasil login ke sistem, dosen dapat melihat daftar surat tugas khusus untuk diri sendiri kemudian dapat mendownload atau mencetak surat tugas tersebut. Sistem diharapkan dapat melayani admin prodi maupun dosen dengan cepat dan tepat. Oleh sebab itu dipilih antar muka yang sederhana dan mudah dipelajari namun dengan fungsionalitas sesuai dengan kebutuhan sehingga diharapkan tidak ada kendala saat terjadi peralihan dari proses pengolahan surat tugas ini dari awalnya manual menjadi menggunakan sistem. Hal ini juga menjadi poin penting dalam mengurangi resistensi dari user.

Sistem harus aktif dalam 24 jam x 7 hari dan bisa diakses dari mana saja. Hal ini penting terutama untuk melayani dosen yang mungkin di saat tertentu membutuhkan untuk mengakses surat tugas dari jauh saat sedang tugas/dinas di luar kota. Oleh karena itu sistem ini dikembangkan dengan tujuan untuk memudahkan admin prodi dalam memenuhi kebutuhan tersebut. Keamanan sistem juga harus terjamin sehingga digunakan sistem login dengan enkripsi password.

\section{HASIL DAN PEMBAHASAN}

Tahapan selanjutnya adalah menganalisis kebutuhan sistem. Sistem dirancang menggunakan arsitektur ClientServer. Bahasa pemrograman yang digunakan adalah $P H P$ dengan database $M y S Q L$. Desain interface akan menggunakan CSS Template. Gambaran sistem akan di desain menggunakan $U M L$.

Pada Gbr 2 merupakan use case diagram [13] yang merupakan gambaran keseluruhan sistem informasi manajemen surat tugas. Kedua aktor dalam use case diagram tersebut adalah Admin Prodi dan Dosen Prodi. Kedua aktor tersebut harus terlebih dahulu login ke dalam sistem untuk dapat menggunakan berbagai fitur dari sistem. Admin Prodi setelah berhasil login ke dalam sistem bisa menggunakan fitur Tambah Surat Baru untuk menambahkan surat tugas baru, fitur Ubah Surat Tugas untuk mngedit surat tugas yang sudah diinputkan, fitur Hapus Surat Tugas untuk menghapus surat 
tugas yang sudah ada, Cari Surat Tugas untuk mencari surat tugas tertentu yang sudah ada di dalam sistem dan fitur Cetak Surat Tugas untuk mencetak surat tugas tertentu. Sedangkan Dosen Prodi setelah berhasil login ke dalam sistem bisa menggunakan fitur Cari Surat Tugas untuk mencari surat tugas tertentu yang sudah pernah dibuat untuk dirinya dan Cetak Surat Tugas untuk mencetak surat tugas tertentu yang sudah pernah dibuat untuk dirinya.

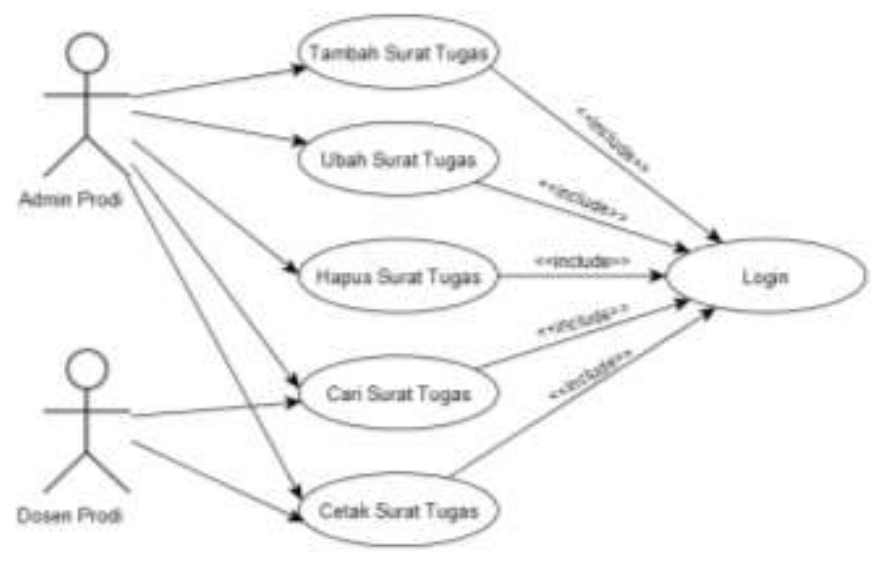

Gbr. 2 Use Case Diagram

Adapun struktur tabel dan relasi antar tabel yang digunakan dalam perancangan sistem informasi surat tugas bisa kita lihat di Tabel 1 sampai Tabel 5. Sedangkan relasi antar tabel untuk pembuatan sistem informasi manajemen surat tugas adalah seperti yang terlihat pada Gambar 3. Diagram alur sistem bisa kita lihat pada Gbr 4. Setelah Admin Prodi berhasil login ke dalam sistem terdapat menu Cari Surat Tugas, jika Admin Prodi ingin mencari surat tugas tertentu maka sistem menampilkan Form Cari. Selanjutnya Admin Prodi dapat mengubah atau menghapus atau langsung mencetak surat tugas tersebut. Jika tidak ingin mencari surat tugas tertentu Admin Prodi dapat langsung menginput surat tugas baru, selanjutnya sistem menampilkan form input surat tugas baru, setelah berhasil disimpan dapat langsung mencetak surat tugas tersebut. Namun, jika tidak ingin menginput surat tugas baru Admin Prodi dapat langsung memilih mengubah atau menghapus atau mencetak surat tugas dari daftar surat tugas yang sudah diinputkan ke sistem sebelumnya.

TABEL I

TABEL JABATAN.SQL

\begin{tabular}{|l|l|l|}
\hline Nama Kolom & Tipe Data & Keterangan \\
\hline id_jabatan & smallint(2) & identitas dari jabatan tertentu \\
\hline Jabatan & char(15) & jabatan tertentu \\
\hline
\end{tabular}

TABEL II

TABEL PETUGAS.SQL

\begin{tabular}{|l|l|l|}
\hline Nama Kolom & Tipe Data & Keterangan \\
\hline id_petugas & $\operatorname{int}(3)$ & identitas dari petugas \\
\hline id_prodi & char(3) & identitas dari program studi \\
\hline nidn & $\operatorname{char}(20)$ & nomor induk dosen nasional \\
\hline nik & $\operatorname{char}(15)$ & nomor induk karyawan \\
\hline nama_petugas & $\operatorname{char}(100)$ & nama petugas \\
\hline id_jabatan & smallint(2) & identitas dari jabatan tertentu \\
\hline
\end{tabular}

TABEL III

TABEL PRODI.SQL

\begin{tabular}{|l|l|l|}
\hline Nama Kolom & Tipe Data & Keterangan \\
\hline id_prodi & char(3) & identitas dari prodi \\
\hline
\end{tabular}

\begin{tabular}{|l|l|l|}
\hline nama_prodi & char(100) & nama program studi \\
\hline
\end{tabular}

TABEL IV

TABEL TRANSAKSI.SQL

\begin{tabular}{|l|l|l|}
\hline Nama Kolom & Tipe Data & Keterangan \\
\hline id_transaksi & $\operatorname{int}(3)$ & identitas dari transaksi \\
\hline no_surat_tugas & char(50) & nomor surat tugas \\
\hline id_prodi & $\operatorname{char}(3)$ & identitas dari prodi \\
\hline id_petugas & $\operatorname{int}(3)$ & identitas dari petugas \\
\hline keterangan & Text & keterangan dari surat \\
\hline tugas & Text & tugas yang dikerjakan \\
\hline hari_awal & char(15) & hari awal tugas \\
\hline hari_akhir & char(15) & hari akhir tugas \\
\hline tanggal_awal & date & tanggal awal tugas \\
\hline tanggal_akhir & date & tanggal akhir tugas \\
\hline jam & char(30) & waktu tugas \\
\hline tempat & char(100) & tempat tugas \\
\hline & & \\
\hline tembusan_1 & char(30) & tembusan 1 surat tugas \\
\hline tembusan_2 & char(30) & tembusan 2 surat tugas \\
\hline tembusan_3 & char(30) & tembusan 3 surat tugas \\
\hline tembusan_4 & char(30) & tembusan 4 surat tugas \\
\hline
\end{tabular}

TABEL

TABEL UNIT.SQL

\begin{tabular}{|l|l|l|}
\hline Nama Kolom & Tipe Data & Keterangan \\
\hline id_unit & smallint(2) & identitas dari unit \\
\hline nama_unit & char(30) & nama unit \\
\hline
\end{tabular}

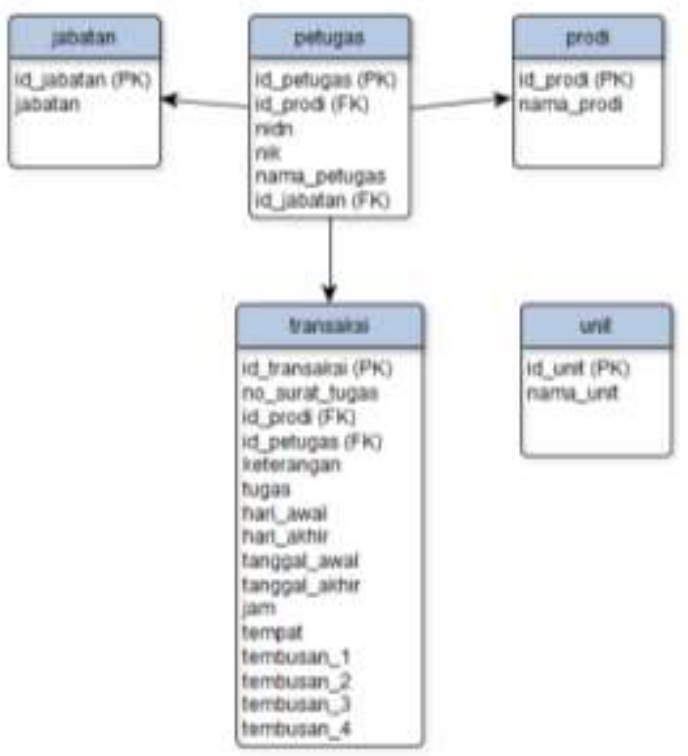

Gbr. 3. Relasi Tabel

Setelah proses desain sistem selanjutnya adalah pemrograman, berikut ini adalah tampilan web sistem informasi manajemen surat tugas untuk fitur input surat tugas seperti yang terlihat pada Gambar 5. 


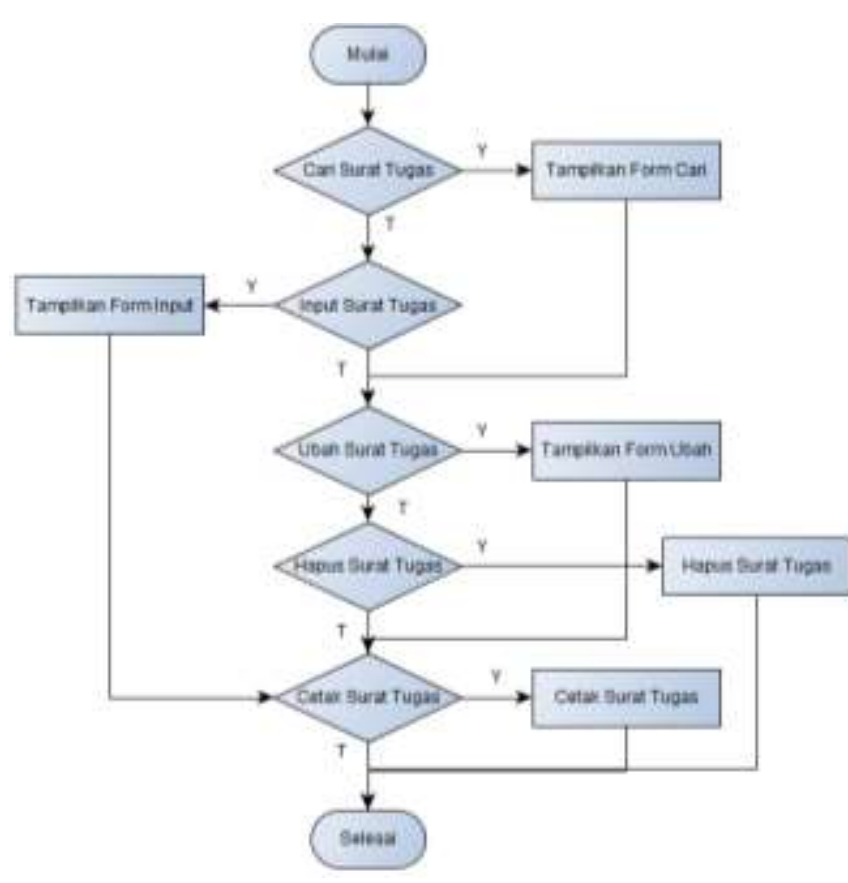

Gbr. 4 Diagram Alur Sistem

Pada halaman input surat tugas ini Admin Prodi dapat memasukan surat tugas baru bagi dosen di Prodi tersebut. No Surat Tugas dihasilkan secara otomatis oleh sistem sesuai dengan format yang ditentukan oleh Universitas, hal ini tentunya sangat membantu kerja Admin Prodi karena Admin Prodi tidak perlu mengingat nomor surat tugas terakhir yang sudah digunakan. Sehingga mengurangi kemungkinan terjadinya human error. Prodi juga menggunakan list dari sistem sehingga Admin Prodi tinggal memilih nama Program Studi dari daftar yang disediakan. Hal ini tentunya juga mempersingkat waktu daripada Admin Prodi harus mengetik berulang-ulang nama Program Studi dan juga mengurangi kemungkinan terjadinya kesalahan pengetikan.

Daftar petugas juga sudah disediakan dalam bentuk list oleh sistem sehingga Admin Prodi tinggal memilih nama petugas yang akan diberikan surat tugas tersebut. Sistem juga secara otomatis sudah menempelkan Nomor Induk Karyawan dari daftar petugas tersebut. Hal ini juga sangat membantu kerja Admin Prodi karena selain mempersingkat waktu juga mengurangi terjadinya kesalahan ketik. Keterangan dan Tugas sudah disediakan Text Area sehingga Admin Prodi tidak perlu khawatir jika yang diinputkan cukup panjang. Hari Awal dan Hari Akhir berupa list sehingga Admin Prodi juga tinggal memilih hari yang sesuai. Tanggal Awal dan Akhir juga berupa kalendar sehingga apabila di pilih muncul kalendar lengkap dengan nama hari dan tahunnya.

Jam dan Tempat berupa Text Box dan Text Area. Disini Admin Prodi harus mengetikan input yang diinginkan. Sedangkan untuk Tembusan 1 sampai Tembusan 4 berupa list sehingga Admin Prodi tinggal memilih nama Departemen atau Program Studi yang akan diberi tembusan. Hal ini juga sangat memudahkan kerja Admin Prodi karena Admin Prodi tidak harus mengingat nama Departemen atau Program Studi satu kampus yang tentunya jumlahnya cukup banyak.
Kemudian yang terakhir adalah dua buah tombol Submit dan Reset. Tombol Submit tentunya digunakan untuk mengirim/memproses isi dari form Input Surat Tugas tersebut sementara tombol Reset digunakan untuk menghapus/membersihkan dari input yang sudah diberikan Admin Prodi namun tidak jadi dikirim.

\section{Input Surat Tugas}

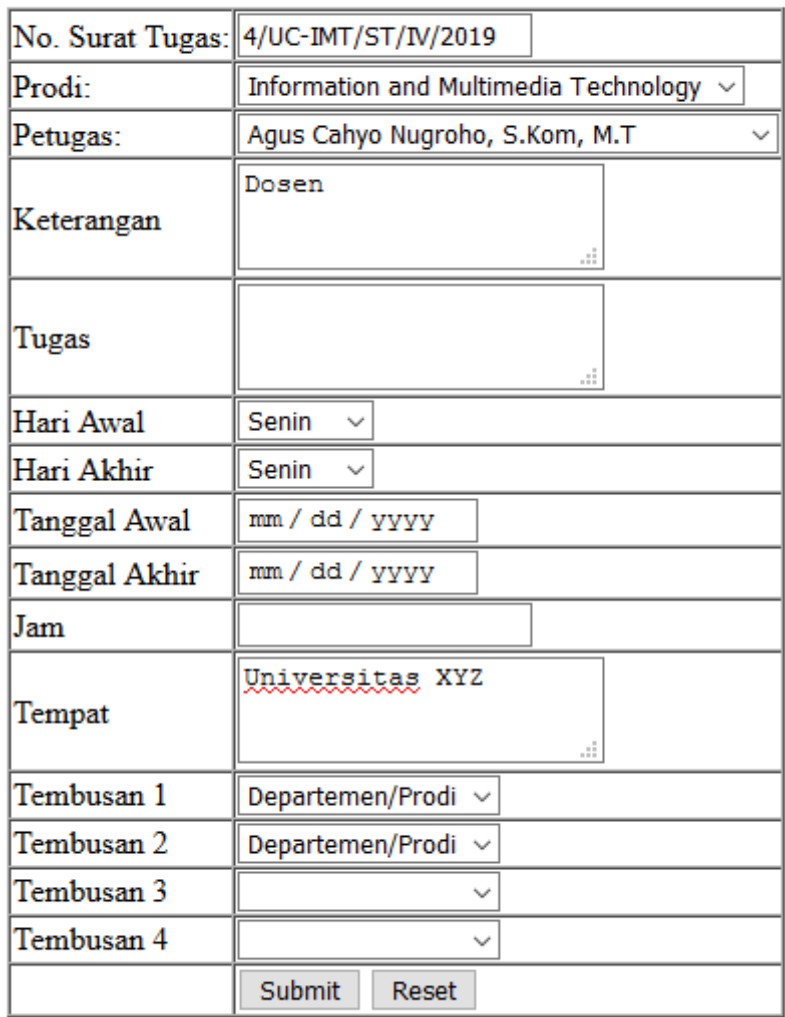

Gbr. 5 Halaman Input Surat Tugas

Halaman berikutnya adalah Daftar Surat Tugas, pada halaman ini terdapat semua surat tugas yang sudah pernah dibuat oleh Admin Prodi. Hal ini sangat penting terkait dengan dokumentasi Program Studi. Semua surat tugas dapat terdokumentasi dengan baik sehingga dapat mendukung saat proses akreditasi Program Studi.

Pada halaman Daftar Surat Tugas pada Gambar 6 terdapat informasi nomor surat tugas, nama dosen, Nomor Induk Karyawan kemudian tiga buah tombol yaitu : Edit untuk mengubah surat tugas tersebut, Delete untuk menghapus surat tugas tersebut dan Print untuk mencetak surat tugas tersebut.

\section{Daftar Surat Tegas \\ \begin{tabular}{|l|l|l|l|l|} 
Ne, Surat Tugas & Nams & NIK & Antian & Repar \\
\hline
\end{tabular}

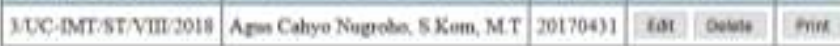

Gbr. 6 Halaman Daftar Surat Tugas

Pada saat kita tekan tombol Print maka sistem akan menghasilkan preview surat tugas tersebut dalam file pdf. Sehingga kita dapat langsung menyimpan file tersebut di komputer atau mencetak surat tugas tersebut. Tampilan dari surat tugas ini bisa kita lihat di Gambar 7. 
SURAT TUGAS

No. : 3UC-IMT/ST/NIII/2018

Ketua/Kepala IMT. Universitas XYZ menugaskan kepada :

\begin{tabular}{|c|c|c|lc|}
\hline No & Nama & NIK & \multicolumn{1}{c|}{ Keterangan } \\
\hline 1 & Agus Cahyo Nugroho, S.Kom, M.T & 20170431 & Dosen & \\
\hline
\end{tabular}

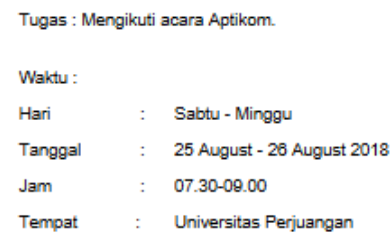

Demikian surat tugas ini dibuat untuk dilaksanakan dengan baik dan penuh tanggung jawa

Semarang, 15 April 2018

Tomi Widodo Nugroho S.T., M.MM.

Ketua/Kepala Program Studi Informatika (IMT)

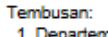

1. Departemen/Prod

2. $\mathrm{HCM}$

Gbr. 7 Tampilan Surat Tugas

\section{Proses Edit}

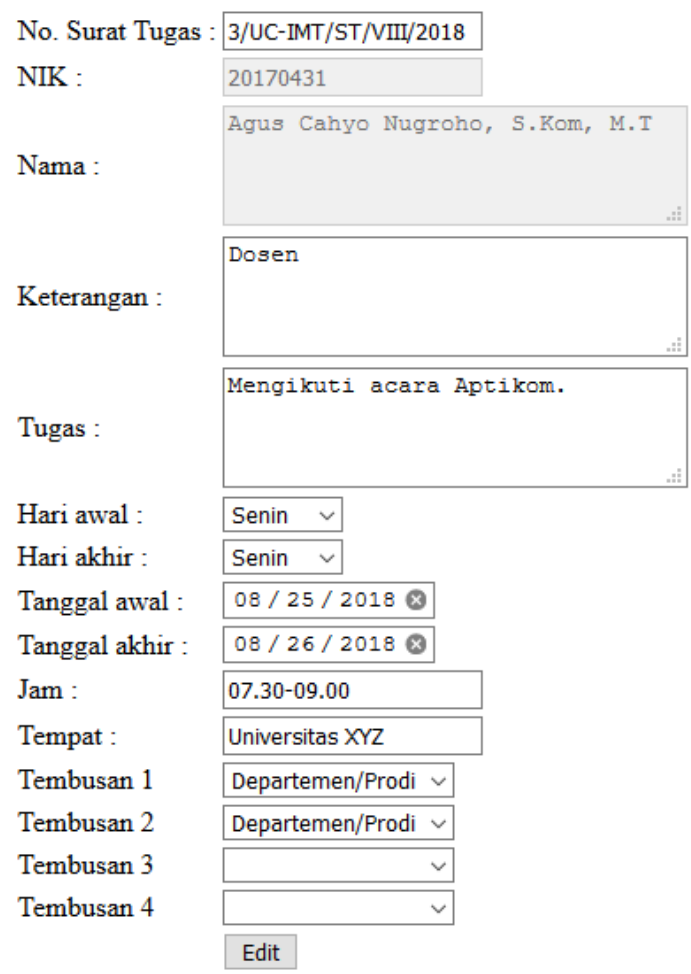

Gbr. 8 Halaman Edit Surat Tugas

Halaman selanjutnya adalah Edit Surat Tugas, pada halaman ini Admin Prodi bisa mengubah isi surat tugas tersebut kecuali kolom Nomor Induk Karyawan dan Nama
Karyawan. Hal ini dilakukan supaya surat tugas tersebut tidak menjadi rancu.

\section{KESIMPULAN}

Kesimpulan yang dapat diambil berdasarkan hasil implementasi dan analisis sistem untuk program penerapan metode waterfall model dalam rancang bangun sistem informasi manajemen surat tugas adalah prosedur pembuatan dan manajemen surat tugas yang ada sekarang kurang dapat memenuhi kebutuhan sebuah PTS di Surabaya. Terutama karena sangat bergantung kepada ketelitian dan kerapian Admin Prodi dalam melakukan manajemen berkas/file. Hal ini bisa menjadi kendala saat beban kerja Admin Prodi sedang tinggi sehingga kemungkinan human error juga semakin tinggi.

Sistem Informasi Manajemen Surat Tugas yang dibuat telah berhasil mengatasi permasalahan tersebut dengan cara mempermudah dan meringankan kerja Admin Prodi. Berkasberkas sudah dalam bentuk digital sehingga memudahkan dalam hal penyimpanan maupun distribusi. Selain itu hal ini juga menguntungkan Dosen Prodi yang dilayani karena sekarang dosen dapat mengakses surat tugasnya dari mana saja selama ada koneksi internet. Terutama saat dosen tugas di luar kota maupun luar negeri dapat langsung mengakses sistem ini ketika membutuhkan surat tugas. Pada penelitian selanjutnya terdapat hal-hal yang bisa ditingkatkan lagi terutama tentang tampilan masih bisa lebih baik lagi. Kemudian ke depan bisa mempertimbangkan untuk mengembangkan versi mobile dari aplikasi ini.

\section{DAFTAR PUSTAKA}

[1] J. Sasongko, DA. Diartono, "Rancang Bangun Sistem Informasi Manajemen Surat," Dinamik. 2009.

[2] M. Luqman, "Pembangunan Sistem Informasi Manajemen Surat Masuk dan Surat Keluar pada Bagian Umum Sekretariat Daerah Kabupaten Pacitan," Speed-Sentra Penelitian Engineering dan Edukasi, 2012.

[3] Supriyanto, A., \& Maulana, Y. M, "Rancang Bangun Aplikas Manajemen Surat Berbasis Web pada Dinas Perhubungan Kota Surabaya," Jurnal JSIKA, 2017.

[4] Praguna, R., Efrizon, E., \& Budayawan, K, "Sistem Informasi Manajemen Kearsipan di SMK Negeri 5 Padang Provinsi Sumatera Barat," Jurnal Vokasional Teknik Elektronika dan Informatika, 2017.

[5] Prawono, J. A., \& Pamungkas, A. R, "Sistem Informasi Pengelolaan Surat Masuk dan Surat Keluar di Stmik Aub Surakarta," Informatika, 2015.

[6] Yani, A, "Analisis dan Perancangan Sistem Informasi Pengelolaan Surat pada STIKOM Dinamika Bangsa Jambi," Jurnal Ilmiah Media Sisfo, 2018.

[7] A. Firman, HF. Wowor, X Najoan, "Sistem Informasi Perpustakaan Online Berbasis Web," Jurnal Teknik Elektro dan Komputer, 2016.

[8] M. Kramer, "Best Practices in Systems Development Lifecycle: An Analyses Based on the Waterfall Model," Review of Business \& Finance Studies, 2018.

[9] YA. Binarso, EA. Sarwoko, N. Bahtiar,'Pembangunan Sistem Informasi Alumni Berbasis Web Pada Program Studi Teknik Informatika Universitas Diponegoro," Journal of Informatics and Technology, 2012.

[10] Z. Efendy, IE. Putra, R. Saputra, "Asset Rental Information System And Web-Based Facilities At Andalas University," Jurnal Terapan Teknologi Informasi, 2018.

[11] JS. Mandiri, "Sistem Informasi Pelayanan Puskesmas Berbasis Web," IJSE-Indonesian Journal on Software Engineering, 2016

[12] M. Viola, RK. Ekawati, T. Wijaya, "Analisis Dan Perancangan Sistem Informasi Akuntansi Penjualan Dan Persediaan Pada PT XYZ," Jurnal Terapan Teknologi Informasi, 2017.

[13] GW. Sasmito, "Penerapan Metode Waterfall Pada Desain Sistem Informasi Geografis Industri Kabupaten Tegal," Jurnal Informatika: Jurnal Pengembangan IT. 2017. 